\title{
Composites based on low-density polyethylene combined with PET- coated SBS paperboard shavings
}

\author{
Maiara Fernanda Gonçalves Holz Goll ${ }^{1}$, Julia Santos Venzon ${ }^{1}$, \\ Atilano Antonio Vegini ${ }^{2}$, Jackson Roberto Eleotério ${ }^{3}$, Lorena Benathar Ballod Tavares ${ }^{1}$
}

\footnotetext{
${ }^{1}$ Programa de Pós Graduação em Engenharia Ambiental, Centro de Ciências Tecnológicas, Universidade Regional de Blumenau, FURB, CEP: 89030 - 000, Blumenau, Santa Catarina, Brasil.

${ }^{2}$ Departamento de Engenharia Química, Centro de Ciências Tecnológicas, Universidade Regional de Blumenau, FURB, CEP: 89030 - 000, Blumenau, Santa Catarina, Brasil.

${ }^{3}$ Departamento de Engenharia Florestal, Centro de Ciências Tecnológicas, Universidade Regional de Blumenau FURB- CEP: 89030 - 000, Blumenau, Santa Catarina, Brasil.
}

e-mail: maiaraholzgoll@gmail.com, jsantos2@furb.br, avegini@furb.br, jreleote@furb.br, lorena@furb.br

\begin{abstract}
In this study, polymer composites comprised of shavings of SBS paperboard coated with polyethylene terephthalate (PET) and recycled low-density polyethylene (LDPE) were obtained. The tensile properties, flexural strength, impact resistance and water absorption were determined according to the standards published by the American Society for Testing and Materials (ASTM). The results show that the composites with the highest concentration of LDPE were more resistant to absorption when exposed to water and humidity. As regards density, a $19.5 \%$ increase of this property was verified for the $30 \%$ cellulosic fiber reinforced composite relative to the pure LDPE density. In relation to the mechanical properties, these samples were found to be very flexible in the elasticity test. The extrusion method provided adequate adhesion between the interfaces of the matrix with the fiber. The composite showed a tensile strength of approximately 55\% larger than that originated by pressing. However, the values for the tensile, flexural and impact strength were lower than expected due to the lack of homogeneity of the SBS paperboard shavings.
\end{abstract}

Keywords: packaging residue, mechanical properties and polymers.

\section{INTRODUCTION}

The intensification of urbanization in recent years, boosted by population growth and the rural exodus has led to changes in production processes in the industrial sector. Every year industrial production increases, since the population growth is a continuous and unlimited process [1]. This is accompanied by technological developments, aimed at improving the quality of life of this new society, which is characterized by consumerism [2]. This has led to major changes in the environment, through the increased consumption of natural resources, and in our lifestyle, including the transformation of eating habits, with the consequent generation of various types of waste $[3,4]$. Food production is one of the main causes of negative environmental impacts [5]. In addition, current eating habits have led to changes in the quality of the human diet and the quantity of products that are available to the consumer, leading to an increase in the consumption of ready-made foods, even considering that home-made food items have a lower cost and a less negative impact on the environment [6]. Some of the main factors that influence patterns of consumption are increased income, demand, urbanization and globalization [7]. These factors have driven consumers to prioritize greater convenience in food preparation, which has boosted the development of semi-finished products and ready-made food, through rapid heating [8]. These food products are mostly packaged in polyethylene terephthalate (PET) and covered with SBS paperboard, the composition of which is $90 \%$ cellulose and $10 \%$ PET [9]. The production of this packaging generates a high quantity of chips (40 tons per month), which are considered as solid waste, with a negative impact on the environment, through global warming, the depletion of fossil fuels and toxicity toward humans [10]. 
Global concern over environmental, human and oil resources has led to the development of new alternatives to address these problems. Composites have arisen as a promising alternative for the use of recycled polymers, allowing improvements in the physical and mechanical properties of products obtained with these polymers [11]. Many conventional raw materials (such as polymers, ceramics and metal alloys) are not compatible with new technologies due to their particular characteristics. However, surprising results can be achieved with the use of composites in manufacturing technologies [12]. Composites are obtained by combining two or more materials that are insoluble in each other, to form a useful engineering material with certain properties that are not provided by the individual materials [13].

The use of cellulose fiber composites as a reinforcing filler for thermoplastic polymers has attracted great interest $[14,15]$. These reinforcements enhance the mechanical, chemical or electromagnetic properties of the composites. Another type of raw material that is generated as waste and can be used in the production of composites is low-density polyethylene (LDPE). According to Coutinho et al. [16], LDPE has a combination of useful properties, such as toughness, high impact strength, high flexibility, good processability, stability and high water resistance. These properties are important for the definition of the use of the composites as well as the methods through which they can be produced.

The aim of this study was to produce composites, applying two methods (pressing and extrusion methods), with an LDPE matrix in different proportions by weight (90, 80 and 70\%), reinforced with PETSBS paperboard (APPET). After their production, the composites were characterized in terms of the moisture content, water resistance, and tensile, flexural and impact strengths. Both materials are waste from the packaging industry, so the use of these was intended to promote their decrease in controlled landfills. The expected contribution from this study is wide, especially the knowledge generated that enables the development of new materials that lead to the reduction of environmental liabilities.

\section{MATERIALS AND METHODS}

The composites were obtained applying two methods. The results of each analysis were interpreted with the aid of statistical treatment using the analysis of variance (ANOVA) and the Tukey test (5\% probability). Thus, for the tables representing the results (Tables 2-7) it was determined that the same letter in a column indicates no significant difference between values $(\mathrm{p}>0.05)$.

\subsection{Origin of residues and preparation of composites by pressing method}

In this study, the waste materials were PET-coated SBS paperboard (APPET) and LDPE provided by a publishing company in Blumenau, Santa Catarina State, Brazil. Initially, the residues were crushed in a Willye mill (model TE-650). The particle size was determined using a Malvern Mastersizer analyzer (model 2000). The samples were weighed on a Marte digital scale (model AD2000) and then subjected to manual homogenization. The mixture was manually distributed uniformly in an aluminum mold of $130 \times 130 \times 5 \mathrm{~mm}$ and covered with a $200 \times 200 \mathrm{~mm}$ plate to avoid direct contact with the heat of the press plates. Three compositions were obtained: 90\% LDPE and 10\% APPET; 80\% LDPE and 20\% APPET and 70\% LDPE and 30\% APPET. The mixtures were pressed at $180{ }^{\circ} \mathrm{C}$ with 12 tons of pressure for 10 min using a Marconi press (model 098 MA/AR15).

\subsection{Preparation of composites by extrusion method}

The residues used in this procedure were the same as those used in the pressing method. The APPET was pounded in a Willye slicer (model TE-650) to homogenize the pellets. The LDPE and APPET were blended followed by the extrusion of the mixture, which had a composition of $90 \%$ LDPE and 10\% APPET. The equipment used was manufactured by KIE Machinery and Plastics Ltda. (model EK 100; 007x05 series, thread $120 \mathrm{~mm}$, LD 28 and $75 \mathrm{hp}$ ). The temperature conditions are shown in Table 1.

Table 1: Extruder temperature conditions.

\begin{tabular}{l|l|l|l|l|l|l}
\hline ZONE & HEAD & $\mathbf{1}$ & $\mathbf{2}$ & $\mathbf{3}$ & $\mathbf{4}$ & $\mathbf{5}$ \\
\hline TEMPERATURE $\left({ }^{\circ} \mathbf{C}\right)$ & 320 & 312 & 270 & 282 & 266 & 211 \\
\hline
\end{tabular}

WATER TEMPERATURE: $25^{\circ} \mathrm{C}$ 
With the pellets obtained by extrusion, the molded composite was pressed applying the pressing method described above.

\subsection{Characterization}

For each composite obtained, the moisture content was determined, in triplicate, according to the standard method ASTM D570 [17]. Samples of each composition were weighed on a Shimadzu analytical balance (model AUY220) and conditioned in an oven at $50^{\circ} \mathrm{C}$ for $24 \mathrm{~h}$. The absorption of water (in percentage terms) was assessed based on the difference in weight after immersion in distilled water $\left(23{ }^{\circ} \mathrm{C}\right)$, for 2 and $24 \mathrm{~h}$, as described in standard method [17]. The density was determined by the water displacement method, immersing a sample of known weight in water for $2 \mathrm{~min}$. The density was calculated as the ratio between the initial mass of the sample and the volume of water displaced, according to the standard method ASTM D1622 [18]. Tensile tests were carried out on each sample specimen using a universal testing machine (EMIC, DL 30,000) according to ASTM D638 [19]. Three samples of each composite were tested. Tests were conducted at a crosshead speed of $5 \mathrm{~mm} \mathrm{~min}^{-1}$ with a load cell of 10,000 N. Three-point flexural tests were conducted according to ASTM D790 [20] on universal testing machine (EMIC, DL 30,000) with a load cell of 10,000 N and a speed of $21.13 \mathrm{~mm}$ min-1. The procedure of the impact resistance test was performed according to ASTM D256 [21] in a EMIC pendulum machine of $2.7 \mathrm{~J}$. Test specimens were prepared with approximately $10 \mathrm{~mm}$ thickness and $79 \mathrm{~mm}$ length.

\section{RESULTS}

\subsection{Moisture content, density and water absorption}

Composites with an LDPE matrix were obtained in different mass proportions, with APPET as a reinforcement in proportions of 10, 20 and 30\%. Figures 1a-c show the pressed plates of APPET/LDPE and Figures 1d-e show the pressed board samples of the extruded material and the pellets obtained by the extrusion process, respectively. 


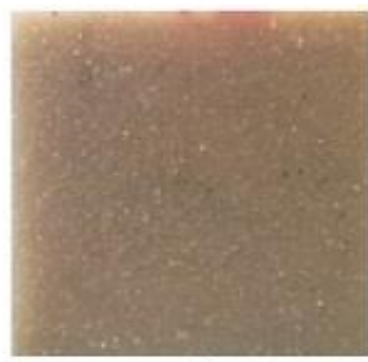

(a)

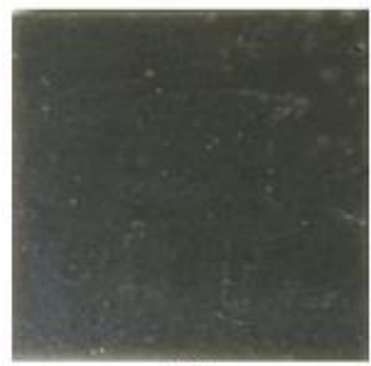

(d)

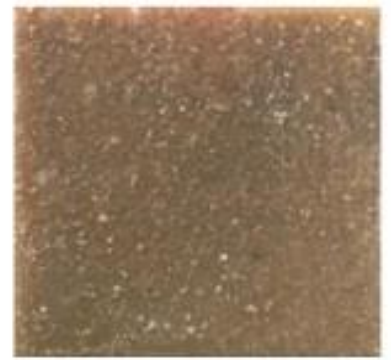

(b)

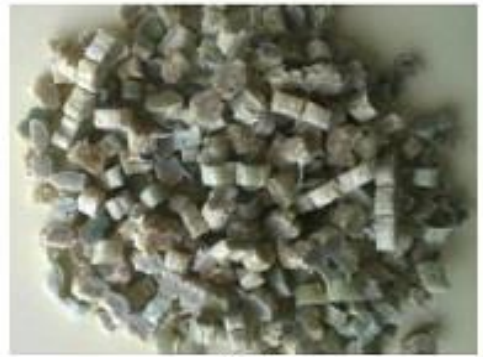

(e)

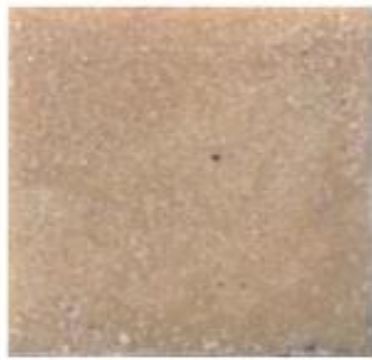

(c)

Figure 1: Plates of APPET: LDPE in ratios (percentage basis) of (a) 10:90, (b) 20:80 and (c) 30:70, of (e) extruded material (10\%APPET and 90\%LDPE) and of (d) pellets (10\%APPET and 90\%LDPE).

Table 2 shows the results for the moisture content of the APPET/LDPE plates in Figures 1a-c, with 10, 20 and $30 \%$ of APPET obtained by the pressing method. The values obtained show a significant difference $(p=0.000042)$, and vary as a function of the amount of APPET used. This is because the PET- coated SBS paperboard has $85 \%$ of cellulose pulp in its composition, as soon the percentage increase of APPET favors the absorption of moisture, a fact that also occurs for the extruded material. The moisture content of the pressed material was much higher than that of the extruded material and these results also show a significant difference $(\mathrm{p}=0.000028)$. A possible explanation for this finding is that during the processing of the composites in the extruder there was a greater dispersion of the load compared with the manual processing.

Table 2: Moisture content of the appet / ldpe specimens obtained by the pressing and extrusion methods

\begin{tabular}{c|c|c}
\hline \multirow{2}{*}{ COMPOSITION } & \multicolumn{2}{|c}{ MOISTURE CONTENT (\%) } \\
\cline { 2 - 3 } & PRESSED & EXTRUDED \\
\hline $10 \%$ APPET / 90\% LPDE & $0.0015 \pm 0.01^{\mathrm{a}}$ & $0.0004 \pm 0.01^{\mathrm{d}}$ \\
\hline $20 \%$ APPET / 80\% LPDE & $0.39 \pm 0.02^{\mathrm{b}}$ & $\mathrm{ND}$ \\
\hline $30 \%$ APPET / 70\% LPDE & $0.69 \pm 0.08^{\mathrm{c}}$ & $\mathrm{ND}$ \\
\hline
\end{tabular}

ND - Not determined

Lignocellulosic fibers are hydrophilic materials due to the presence of hydroxyl groups in their structure [22, 23, 24] and thus exhibit poor resistance to moisture. The availability of hydroxyl groups produces regions in which water adsorption occurs. Therefore, a layer with several molecules of water will be formed around the surface of the fibers. As a result of the entry of water, the cell wall of these fibers undergoes distancing, resulting in the expansion of the material [23,25]. For this reason, moisture becomes a factor that can directly reflect on the mechanical and energetic properties of the composite material reinforced with lignocellulosic fibers [26]. Due of hygroscopicity, the natural fibers may decrease the mechanical strength of the composite material relative to the strength of the material composing the matrix. Hygroscopicity also reduces the calorific value of the composite material due to evaporation of water at the start of combustion [23,24]. Thus, the low moisture content of the lignocellulosic fibers decreases the size variation. This can improve the interaction between the matrix and the reinforcing material, avoiding variation in the size of the fibers of the composite material during the loss (decrease) or natural gain (increase) of ambient moisture content. Marinho 
et al. [27] evaluated the moisture content of polyurethane (PU) composites reinforced with 10, 15 and $20 \%$ of bamboo fibers and obtained an average value of $9.2 \%$. The results reported are lower ( $8.9 \%$ less, on average) compared with the moisture content of the APPET/LDPE samples (obtained applying the two methods studied). This could be because the bamboo underwent thermal degradation at $90{ }^{\circ} \mathrm{C}$ at the time of pressing and contains constituents with a high affinity for water [27, 28].

The composite density results varied between 0.86 and $1.10 \mathrm{~g} . \mathrm{cm}^{-3}$, presenting a significant difference $(p=0.00)$, and the values increased with the concentration of APPET (Table 3). This can be attributed to the amount of cellulosic fiber present in the composites, that is, the higher the percentage of cellulose fibers (APPET) the higher the density will be. A study by Caraschi et al. [29] on the production and characterization of polypropylene containing composites reinforced with elephant grass fibers showed no significant difference between the density of pure polypropylene and the composite reinforced with $15 \%$ fibers $(0.88$ g. $\left.\mathrm{cm}^{-3}\right)$. However, when the elephant grass fiber reinforcement was $25 \%$, the composite density increased significantly to $0.91 \mathrm{~g} . \mathrm{cm}^{-3}$, indicating that the increase in the percentage of cellulosic fibers causes density to increase [29]. The same phenomenon can be explained by the effect of the filling load on the density of the palm tree reinforced polyester composites [15]. In the study by Nabinejad et al. [15] the results showed that the density of the composites increased gradually as the filling content increased. The increase in density was

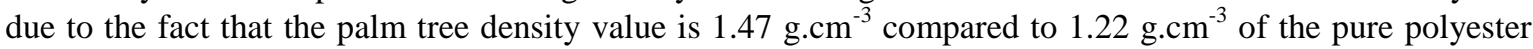
resin. This also occurs with poly (L-lactic acid) matrix composites reinforced by sawdust. Composites containing $40 \%$ sawdust showed $7 \%$ increase in density compared to pure poly (L lactic acid) [30]. This fact was expected because the density of wood sawdust (1.72 g.cm-3) was higher than that of poly (L-lactic acid) (1.25 g.cm-3) [30]. The opposite trend was observed for composites of LDPE-Al reinforced with 10, 20 and $30 \%$ of fiberglass studied by Hidalgo-Salazar et al. [31]. The density of the composites decreased as the amount of fibers in the material increased, obtaining a mean density of $1.06{\mathrm{~g} . \mathrm{cm}^{-3}}^{-}$This could be due to the formation of an interface between the composite phases [31]. The mentioned studies allow the understanding that the density of the lignocellulosic composites is related to the proportion of the fibrous reinforcements. As it also concerns the difference between the density values of the material making up the matrix and the reinforcement. In relation to the density values for the specimens obtained applying the two methods studied, a significant difference can be observed $(\mathrm{p}=0.00162)$ between the extruded and compressed samples. Since the samples obtained by the pressing method were mixed manually, this difference could be due to a lack of homogeneity of the particles used to obtain the composite. Yang et al. [12] noted that this lack of homogeneity is one of the difficulties associated with preparing composites. However, the results are similar to those reported by Coutinho et al. [16], who studied the properties of polyethylene and obtained a density of 0.92 g. $\mathrm{cm}^{-3}$ for LDPE.

Table 3 : Density of the appet / ldpe specimens obtained by the pressing and extrusion methods

\begin{tabular}{c|c|c}
\hline \multirow{2}{*}{ COMPOSITION } & \multicolumn{2}{|c}{ DENSITY $\left(\mathbf{g} / \mathbf{c m}^{3}\right)$} \\
\cline { 2 - 3 } & PRESSED & EXTRUDED \\
\hline $10 \%$ APPET / 90\% LPDE & $0.86 \pm 0.01^{\mathrm{a}}$ & $0.92 \pm 0.00^{\mathrm{d}}$ \\
\hline $20 \%$ APPET / $80 \%$ LPDE & $0.94 \pm 0.01^{\mathrm{b}}$ & ND \\
\hline $30 \%$ APPET / 70\% LPDE & $1.10 \pm 0.00^{\mathrm{c}}$ & ND \\
\hline
\end{tabular}

ND - Not determined

Table 4 shows the water content after $2 \mathrm{~h}$ of immersion in water for the different percentages of the composites pressed. Evaluating this result, it was observed that the lack of homogeneity, due to the mixture being performed manually, promoted significant differences $(p=0.039)$ in terms of water absorption. Even with the lack of homogeneity, the opposite result was obtained after $24 \mathrm{~h}$ of immersion in water, and the differences in the values were not significant $(p=0.67)$. This can be attributed to the fact that the sample becomes saturated with water, due to the affinity of APPET for water. The greater the amount of cellulose (with a polar nature) present the greater the sample affinity for water will be.

Ligowski et al. [32] studied the properties of composites of high density polyethylene and polystyrene reinforced with sugarcane bagasse in the proportions of 30 and 50\%. The absorption tests showed that the higher proportion of fiber increases the water absorption in the composites. This is expected due to the hygroscopic characteristics of the lignocellulosic fibers of sugarcane bagasse [32]. This phenomenon can also be observed in composites of poly (L-lactic acid) reinforced with wood residues [30], in which the water ab- 
sorption of pure poly (L-lactic acid) was lower than the absorption in the composites. Sawdust exerted a great influence on the water absorption rate of the composites due to their high hydrophilicity [30]. The same happened for composites with orthophthalic polyester resin matrix reinforced with medium-density fiberboard (MDF) residues [33]. In these composites, the water absorption indices were approximately 2.0, 4.3 and $4.7 \%$ respectively for 10,15 and $20 \%$ reinforcement content.

The results for the extruded materials (Table 4), after both $2 \mathrm{~h}$ and $24 \mathrm{~h}$, showed no significant differences with variations in the percentage of APPET ( $p=0.649$ ), and the absorption in both cases was $0.04 \%$. This could be because the samples contain only $10 \%$ of APPET and the LDPE has no affinity with water, that is, the higher the amount of polymer the lower the water absorption of the specimen will be. In general, composites formed by polymer matrix and reinforced by lignocellulosic fibers absorb small amount of water if they are produced in such a way that the reinforcement component is fully encapsulated by the polymer [34]. Therefore, the water absorption of the composite obtained in this study were APPET sufficiently well encapsulated by the LDPE, since water absorption by the composite index was low. However, another factor influencing this result is that the APPET did not completely melt in the extruder, i.e., the pellets, and consequently the plates, were not completely homogeneous. Because of this, some samples may contain $10 \%$ or less of APPET.

Table 4: Absorption after $2 \mathrm{~h}$ and $24 \mathrm{~h}$ of immersion in water for appet / ldpe specimens obtained by the pressing and extrusion methods.

\begin{tabular}{l|c|c|c|c}
\hline \multirow{2}{*}{ COMPOSITION } & \multicolumn{4}{|c}{ WEIGHT (\%) } \\
\cline { 2 - 5 } & \multicolumn{2}{|c|}{ PRESSED } & \multicolumn{2}{c}{ EXTRUDED } \\
\cline { 2 - 5 } & $\mathbf{2}$ HOURS & $\mathbf{2 4}$ HOURS & $\mathbf{2}$ HOURS & 24 HOURS \\
\hline $10 \%$ APPET / 90\% LPDE & $0.10 \pm 0.04^{\mathrm{a}}$ & $0.88 \pm 0.05^{\mathrm{a}}$ & $0.04 \pm 0.01^{\mathrm{d}}$ & $0.04 \pm 0.02^{\mathrm{d}}$ \\
\hline $20 \%$ APPET / 80\% LPDE & $0.37 \pm 0.00^{\mathrm{ab}}$ & $0.80 \pm 0.02^{\mathrm{a}}$ & ND & ND \\
\hline $30 \%$ APPET / 70\% LPDE & $0.43 \pm 0.04^{\mathrm{b}}$ & $1.23 \pm 0.02^{\mathrm{a}}$ & ND & ND \\
\hline
\end{tabular}

ND - Not determined

\subsection{Tensile test}

Table 5 shows the mean tensile strength values for the specimens tested. It can be observed that the addition of APPET to LDPE decreases the rupture resistance and the elasticity, indicating less transfer of stress from the matrix to the reinforcement. The decrease in the tensile strength and elasticity values of the composites studied in this work, due to the increase in the content of APPET, can be explained, in part, to the hydrophobic behavior of the LDPE. The opposite is observed with the lignocellulosic fibers, which show hydrophilic behavior, resulting in low interfacial adhesion between the polymer phase and the fibrous phase [29]. According to Garcia et al. [35], a lack of adequate compatibility between the fibers and the matrix leads to insufficient interfacial adhesion, which affects the mechanical properties. For deformation, it is important to increase its percentage in relation to the intensification of APPET content, since this parameter is inversely proportional to the modulus of elasticity [29]. On comparing the rupture strength results for the specimens obtained with the two methods (pressing and extruding) a significant difference is observed $(p=0.00)$. Similarly, the deformation results for the specimens showed a significant difference $(p=0.035)$. In contrast, the elasticity results did not show a significant difference $(p=0.11)$. Khoffi et al. [36] studied composites of PET and copper filaments and obtained an elasticity of $64.19 \%$, a value very similar to those obtained in this study. On analyzing the results for the specimens obtained only from the pressing method, there were no significant differences for the resistance to fracture, elasticity and deformation $(\mathrm{p}=0.11,0.72$ and 0.21 , respectively). In the study by Bittencourt et al. [30], sawdust reinforced poly (L - lactic acid) composites also showed a decrease in tensile strength as the percentage of residue incorporated in the sample increased. The same occurred for deformation. However, the elasticity had a significant increase with the increase of the sawdust concentration [30]. A similar behavior occurred in the study by Gomes et al. [33] where the mechanical tensile strength of MDF-reinforced polyester resin composites was analyzed. The MDF residues in the composite did not function as a reinforcement, but as a filler, since it reduces tensile strength and deformation when its content in the sample is increased [33]. 
Table 5 : Mean values for the fracture strength, deformation and modulus of elasticity for composites with 10, 20 and $30 \%$ appet obtained by pressing and $10 \%$ appet obtained by extrusion.

\begin{tabular}{c|c|c|c|c|c|c}
\hline \multirow{2}{*}{ Composition } & \multicolumn{3}{|c|}{ PRESSED } & \multicolumn{3}{c}{ EXTRUDED } \\
\cline { 2 - 7 } & $\begin{array}{c}\text { Fracture } \\
\text { strength } \\
(\mathbf{M P a})\end{array}$ & $\begin{array}{c}\text { Deformation } \\
(\boldsymbol{\%})\end{array}$ & $\begin{array}{c}\text { Elasticity } \\
(\mathbf{M P a})\end{array}$ & $\begin{array}{c}\text { Fracture } \\
\text { strength } \\
(\mathbf{M P a})\end{array}$ & $\begin{array}{c}\text { Deformation } \\
(\%)\end{array}$ & $\begin{array}{c}\text { Elasticity } \\
(\mathbf{M P a})\end{array}$ \\
\hline $10 \%$ APPET & $5.79 \pm 0.18^{\mathrm{a}}$ & $0.04 \pm 0.01^{\mathrm{a}}$ & $73.70 \pm 2.37^{\mathrm{a}}$ & $8.99 \pm 0.01^{\mathrm{b}}$ & $0.12 \pm 0.03^{\mathrm{b}}$ & $\begin{array}{c}70.04 \pm \\
2.10^{\mathrm{a}}\end{array}$ \\
\hline $20 \%$ APPET & $4.05 \pm 0.41^{\mathrm{a}}$ & $0.04 \pm 0.01^{\mathrm{a}}$ & $61.69 \pm 1.25^{\mathrm{a}}$ & $\mathrm{ND}$ & $\mathrm{ND}$ & $\mathrm{ND}$ \\
\hline $30 \%$ APPET & $3.72 \pm 0.16^{\mathrm{a}}$ & $0.06 \pm 0.02^{\mathrm{a}}$ & $45.42 \pm 9.11^{\mathrm{a}}$ & $\mathrm{ND}$ & $\mathrm{ND}$ & $\mathrm{ND}$ \\
\hline
\end{tabular}

ND - Not determined

\subsection{Flexural test}

The results for the flexural modulus and the deformation of the samples are given in Table 6. On analyzing the results for the bending stress, it can be observed that the values increase with the content of APPET present in the composite, but there was no significant difference $(p=0.42)$. Redighieri and Costa [37] analyzed the same thermoplastic composites, but the samples contained 40, 50 and $60 \%$ of eucalyptus particles. The authors observed an increase in the flexural modulus according to the content of these particles $(3.173,3.989$ and $3.528 \mathrm{MPa}$, respectively). However, Feldman and Barbalata [38] reported that the flexural stress of LDPE is in the range of 415 to $795 \mathrm{MPa}$, that is, the composites lost flexibility due to the presence of APPET. However, it is seen that the flexural modulus of the constituents has an important effect on the flexural modulus of the final compound. Therefore, how bigger the modulus of the reinforcing constituents, can be expected to increase of the flexural modulus [34]. The slight decrease in the flexural stress of the composite with $20 \%$ of APPET is possibly influenced by the composition of the blends. An increase in the amount of APPET particles could lead to a decrease in the homogenization of the matrix and the dispersed phase, leading to a decrease in the mechanical properties of this material when a compatibilization agent is not present [37]. The work of Ligowski et al. [32] also showed an increase in flexural strength for high-density polyethylene (HDPE) and polystyrene (PS) composites in relation to the increase of sugarcane fiber content in the composition, with a better stress distribution. For the HDPE matrix, the flexural strength values were 39 and $45 \mathrm{MPa}$, while for the PS matrix, these values became 33 and $38 \mathrm{MPa}$, considering the reinforcement contents of 30 and $50 \%$, respectively, for both composites [32]. This same relationship occurred in the study of Nabinejad et al. [15], whose polyester composite reinforced with $9 \%$ by mass of palm fiber showed $16 \%$ larger flexural strength when compared to pure polyester. The results for the deformation and the elasticity of the samples obtained by the pressing method did not show significant differences $(\mathrm{p}=0.87$ and 0.55 , respectively). Similarly, on comparing the samples obtained with the two methods (pressing and extrusion), there was no significant difference in terms of the flexural strength $(p=0.31)$ and elasticity $(p=0.39)$, but for the deformation there was a significant difference $(\mathrm{p}=0.00)$.

Regarding the modulus of elasticity, although it does not present significant difference, its increase is perceptible in relation to the increase of the percentage of APPET in the samples. In the study by Jesus et al. [24], the same was obtained for recycled PS composites reinforced with cellulose from sugarcane bagasse in proportions of 10 and $20 \%$ by mass, whose elasticity increase was 18 and $30 \%$, respectively, compared to recycled PS. The flexural modulus and the modulus of elasticity are magnitudes directly proportional, since the higher the value for elasticity larger the effort to be made to deform a material [24]. Thus, it is possible that the results obtained for flexural strength and modulus of elasticity indicate an appropriate transfer of stress from the LDPE matrix to the reinforcement of APPET. 
Table 6 : Mean values for flexural strength and flexural strain of composites with 10, 20 and 30\% appet obtained by pressing and $10 \%$ appet obtained by extrusion.

\begin{tabular}{l|c|c|c|c|c|c}
\hline \multirow{2}{*}{ Composition } & \multicolumn{3}{|c|}{ PRESSED } & \multicolumn{3}{c}{ EXTRUDED } \\
\cline { 2 - 7 } & $\begin{array}{c}\text { Flexural } \\
\text { strength } \\
(\mathbf{M P a})\end{array}$ & $\begin{array}{c}\text { Flexural } \\
\text { strain } \\
(\mathbf{m m} / \mathbf{m m})\end{array}$ & $\begin{array}{c}\text { Elasticity } \\
(\mathbf{M P a})\end{array}$ & $\begin{array}{c}\text { Flexural } \\
\text { strength } \\
(\mathbf{M P a})\end{array}$ & $\begin{array}{c}\text { Flexural } \\
\text { strain } \\
(\mathbf{m m} / \mathbf{m m})\end{array}$ & $\begin{array}{c}\text { Elasticity } \\
(\mathbf{M P a})\end{array}$ \\
\hline $10 \%$ APPET & $11.27 \pm 0.11^{\mathrm{a}}$ & $0.15 \pm 0.01^{\mathrm{a}}$ & $438.94 \pm 12.64^{\mathrm{a}}$ & $11.05 \pm 0.67^{\mathrm{a}}$ & $0.11 \pm 0.00^{\mathrm{b}}$ & $433.95 \pm 32.71^{\mathrm{a}}$ \\
\hline $20 \%$ APPET & $11.00 \pm 0.00^{\mathrm{a}}$ & $0.15 \pm 0.00^{\mathrm{a}}$ & $437.69 \pm 10.59^{\mathrm{a}}$ & $\mathrm{ND}$ & $\mathrm{ND}$ & $\mathrm{ND}$ \\
\hline $30 \%$ APPET & $11.55 \pm 0.12^{\mathrm{a}}$ & $0.15 \pm 0.00^{\mathrm{a}}$ & $478.47 \pm 11.02^{\mathrm{a}}$ & $\mathrm{ND}$ & $\mathrm{ND}$ & $\mathrm{ND}$ \\
\hline
\end{tabular}

ND - Not determined

\subsection{Impact resistance test}

Table 7 shows the results obtained in the Izod impact test. The results for the impact resistance showed linearity with the proportion of APPET in the samples, but there was no significant difference between the values $(p=0.85)$. This could be related to the thermomechanical degradation of the APPET fibers [39]. Another factor contributing to this result is the lack of homogeneity of the samples due to the manual mixing in the preparation of the composites. Santos et al. [40] noted that the presence of fibers can decrease the energy absorbed by composites and create regions of concentrated stress, leading to lower energy results in the impact tests. Soucy et al. [41] studied composites of high-density polyethylene reinforced with 20,30 and $40 \%$ pulp from the paper industry and obtained an average value of $155.83{\mathrm{~J} . \mathrm{m}^{-1}}^{-1}$. It was observed a reduction of the impact energy as the reinforcement mass increased. In the study by Gomes et al. [22], composites formed by HDPE reinforced with $10 \%$ of banana fiber showed a $247 \%$ improvement in impact resistance properties compared to pure HDPE. However, the percentage decreases with the increase of fibers in the composite, with a reduction of $20 \%$ in relation to the pure polymer when $40 \%$ reinforcement is added in the composite [22].

In this study with APPET, another explanation for the decrease of the modulus of impact resistance in relation to the increase of fiber concentration in the composite is the low affinity between the matrix and the reinforcement. This is due to the hydrophilic character of the cellulose in the APPET, reducing adhesion with the LDPE matrix [22,29]. Mirmehdi et al. [34] carried out a study with the objective was to evaluate the influence of the amount and aspect of the lignocellulosic reinforcement on the mechanical properties of LDPE matrix composites. It was verified that the shape and size of the lignocellulosic fibers consist of the main factors of the decrease of the impact resistance of composites with larger amount of reinforcement. When the impact force is applied to the composite, the stress concentration causes sample to rupture in the interface area between the reinforcement and the die. Therefore, the reinforcement of longer fibers can withstand larger impact forces [34].

On evaluating the results for the impact resistance of samples obtained applying the two methods, the values were very close and did not present a significant difference $(p=0.93)$. This finding is of interest since in this research recycled materials were used without compatibilization agents and future research should include a chemical analysis of the material.

Table 7: Impact strength for pressed and extruded material.

\begin{tabular}{|c|c|c|}
\hline \multirow{2}{*}{ Composition } & PRESSED & EXTRUDED \\
\hline & Izod impact test $\left({\left.\mathrm{J} . \mathrm{m}^{-1}\right)}^{-1}\right.$ & Izod impact resistence $\left(\mathrm{J} . \mathrm{m}^{-1}\right)$ \\
\hline $10 \%$ APPET & $22.69 \pm 0.42^{\mathrm{a}}$ & $22.45 \pm 1.01^{\mathrm{a}}$ \\
\hline $20 \%$ APPET & $18.73 \pm 0.10^{\mathrm{a}}$ & ND \\
\hline $30 \%$ APPET & $18.18 \pm 0.00^{\mathrm{a}}$ & ND \\
\hline
\end{tabular}

ND - Not determined 


\section{CONCLUSIONS}

In this work, matrix composites of LDPE residues were obtained with addition of residues of SBS paperboard with PET, in the mass proportions of 10, 20 and $30 \%$, by means of two techniques: pressing and extrusion. These composites were submitted to moisture, water absorption, density, tensile, flexural and impact assay, in order to investigate the physical and mechanical characteristics of the composite. Analyzing the mean values of moisture content and water absorption for the composite samples obtained by the pressing method, a significant increase of these values is verified in accordance with the increase of APPET in the composite. However, such values for both moisture and water absorption were very low. As regards density, there was a gradual increase according to the addition of reinforcing material (fibers). The density of the $30 \%$ APPET reinforced composite was $19.5 \%$ higher compared to the pure LDPE density.

As for the mechanical properties, tensile assay showed a tendency to decrease the tensile strength and elasticity modulus according to the increase of fibers in the composite, even if the values did not have significant differences. For the composites with $10 \%$ reinforcement of APPET of both techniques studied, it was verified that the composite obtained by extrusion presents tensile strength of approximately $55 \%$ greater than that originated by the pressing. This allows concluding that the extrusion method provided better adhesion between the matrix interface and the fiber. For the flexural and impact assays, the comparison between the composites reinforced with $10 \%$ of APPET obtained by the pressing method resulted in a higher resistance than that obtained by the extrusion method.

\section{ACKNOWLEDGEMENTS}

The authors are grateful to CNPq for the master's and productivity grants (DT) and to MCTIC / CNPq for financial support (Grant 402593/2013-8).

\section{BIBLIOGRAFY}

[1] SOUSA, C.C., ALVES, A.L., ZANFOLIM, A.A., et al., "Aplicação e estudo das propriedades físicas do resíduo de garrafas pet trituradas na conformação de blocos vazados de concreto: Classificação", In: III ENIC - Encontro Internacional de Iniciação Científica, pp. 1-13, Minas Gerais, Oct. 2014.

[2] SALA, S., ANTON, A., MCLAREN, S.J., et al., "In quest of reducing the environmental impacts of food production and consumption", Journal of Cleaner Production, v. 140, p. 387-398, Jan. 2017.

[3] BALDINI, C., GARDONI, D., GUARINO, M., "A critical review of the recent evolution of Life Cycle Assessment applied to milk production”, Journal of Cleaner Production, v. 40, p. 421-435, Jan. 2017.

[4] NOTARNICOLA, B., SALA, S., ANTON, A., et al., "The role of life cycle assessment in supporting sustainable agri-food systems: A review of the challenges", Journal of Cleaner Production, v. 140, p. 399409, Jan. 2017.

[5] NOTARNICOLA, B., TASSIELLI, G., RENZULLI, P.A., et al., "Environmental impacts of food consumption in Europe", Journal of Cleaner Production, v. 40, pp. 753-765, Jan. 2017.

[6] RIVERA, X.C.S., AZAPAGIC, A., "Life cycle costs and environmental impacts of production and consumption of ready and home-made meals", Journal of Cleaner Production, v. 112, pp. 214-228, Jan. 2016.

[7] MARATOYA, E.E., CARVALHAES, G.C., WANDER, A.E., et al., "Mudanças no padrão de consumo alimentar no Brasil e no mundo”, Revista de Política Agrícola, v. 22, n. 1, pp. 72-84, Jan. 2013.

[8] CAJAVILCA, E.S.R., MARQUE, N.S., MELO, E.M., et al., "Análise de patentes do mercado de alimentos industrializados no mundo com base na classificação "A" da Wipo", Cadernos de Prospecção, v. 7, n. 4, pp. 612-621, Oct./Dec. 2014.

[9] FERRI, G.N., HERMANN, K.L., WISBECK, E., et al., "Evaluación de la influencia de los factores físicos y nutricionales en la propagación del micelio de Pleurotus sajor-caju ccb-019 en biomasa residual de embalaje de alimentos", Revista CSBEA, v. 1, n. 1, p. 1-6, 2015.

[10] GALLEGO, A.S., MENDONZA, J.M.F., JESWANI, H.K., et al., "Life cycle environmental impacts of vacuum cleaners and the effects of European regulation”, Science of The Total Environment, v. 559, pp. 192-203, July 2016. 
[11] SATYANARAYANA, K.G., ARIZAGA, G.C., WYPYCH, F., "Biodegradable composites based on lignocellulosic fiber - an overview”, Progress in Polymer Science, v. 34, pp. 982-1021, Set. 2009.

[12] YANG, Y., BOOM, R., IRION, B., et al., "Recycling of composite materials Yongxiang”, Chemical Engineering and Processing: Process Intensification, v. 51, p. 53-68, Jan. 2012.

[13] ASTM D3878: Standard Terminology for Composite Materials. (2015, July 1). August, 2015. Estados Unidos: ASTM International.

[14] MIRMEHDI, S.M., TONOLI, G.H.D., DABBAGH, F. "Lignocellulose-polyethylene composite: influence of delignification, filler content and filler type", Cellulose Chemistry and Technology, v. 51, p. 341-346, May 2017.

[15] NABINEJAD, O., SUJAN, D., RAHMAN, M.E., et al., "Effect of filler load on the curing behavior and mechanical and thermal performance of wood flour filled thermoset composites", Journal of Cleaner Production, v. 164, p. 1145-1156, Oct. 2017.

[16] COUTINHO, F.M.B., MELLO, I.L., MARIA, L.C.S., "Polietileno: principais tipos, propriedades e aplicações", Polímeros, v. 13, n. 1, pp. 1-13, Jan./Mar. 2003.

[17] ASTM D570: Standard Test Method for Water Absortion of Plastics. (2010, April 1). June, 2010. United States: ASTM International.

[18] ASTM D1622: Standard Test Method for Water Absortion of Plastics. (2010, April 1). June, 2010. United States: ASTM International.

[19] ASTM D638: Standard Test Method for Apparent Density of Rigid Cellular Plastics. (2014, April 1). May, 2015. United States: ASTM International.

[20] ASTM D790: Standard Test Method for Flexural Properties of Unreinforced and Reinforced Plastics and Electrical Insulating Materials. (2010, April 1). April, 2010. United States: ASTM International.

[21] ASTM D256: Standard Test Method for Determining the Izod Pendulum Impact Resistance of Plastics. (2010, May 1). June, 2010. United States, ASTM International.

[22] GOMES, T. S., VISCONTE, L. L. Y., PACHECO, E. B. A. V., "Substituição da fibra de vidro por fibra de bananeira em compósitos de polietileno de alta densidade: Parte 1 avaliação mecânica e térmica", Polímeros, v. 23, n. 2, pp. 206-211, Feb. 2013.

[23] SILVA, D. A., DA RÓZ, A. L., PIRES, A. A. F., et al., “A Influência da Umidade em Propriedades Mecânicas de Briquetes Produzidos com Resíduos de Madeira (Eucalyptus sp. e Pinus sp.)", Revista Virtual de Química, v. 9, n. 3, pp. 1078-1086, May 2017.

[24] JESUS, L. C. C., LUZ, S. M., LEÃO, R. M., et al., "Propriedades mecânicas de compósitos de poliestireno reforçado com celulose de bagaço de cana", Revista Interdisciplinar de Pesquisa em Engenharia, v. 1, n. 1 pp. 1-14, 2015.

[25] NAKASHIMA, G. T., ADHMANN, I. C. S., HANSTED, A. L. S., et al., "Materiais lignocelulósicos: caracterização e produção de briquetes”, Revista Virtual de Química, v. 9, n. 1, pp. 150-162, Jan.-Feb. 2017.

[26] HANSTED, A. L. S., NAKASHIMA, G. T., MARTINS, M. P., et al., "Coparative analyses of fast growing species in different moisture content for high quality solid fuel production”, Fuel, v. 184, pp. 180184, Nov. 2016.

[27] MARINHO, N.P., NASCIMENTO, E.M., NISGOSKI, S., et al., "Caracterização física e térmica de compósito de poliuretano derivado de óleo de mamona associado com partículas de bambu", Polímeros, v. 23, n. 2, pp. 201-205, 2013.

[28] ZHANG, Y.M., YU, Y.L., YU, W.J., "Effect of thermal treatment on the physical and mechanical properties of phyllostachys pubescen bamboo", European Journal of Wood and Wood Products , v. 71, n. 1, pp. 61-67, Jan. 2013.

[29] CARASCHI, J, C., PRATES, G. A., LEÃO, A. L., et al., "Compósitos de polipropileno reforçado com capim-elefante”, Brazilian Journal of Biosystems Engineering, v. 9, n. 3, pp. 236-246, Set. 2015.

[30] BITENCOURT, S. S., BATISTA, K. C., ZATTERA, A. J., et al., "Desenvolvimento de biocompósitos de poli(L-áciso lático) com serragem de madeira”, Revista Matéria, v. 22, n. 4, [online], Oct. 2017.

[31] HIDALGO-SALAZAR, M.A., MUNOZ, M.F., MINA, J.H., "Influence of corporation of natural fibers on the physical, mechanical, and thermal properties of composites LDPE-Al Reinforced with fique fibers", International Journal of Polymer Science, v. 2015, pp. 1-8, 2015. 
[32] LIGOWSKI, E., SANTOS, B. C., FUJIWARA, S. T., "Materiais compósitos a base de fibra de cana-de açúcar e polímeros reciclados obtidos através da técnica de extrusão", Polímeros, v. 25, n. 1, pp. 70-75, 2015.

[33] GOMES, J. W., GODOI, G. S., SOUZA, L. G. M., et al., "Absorção de água e propriedades mecânicas de compósitos poliméricos utilizando resíduos de MDF", Polímeros, v. 27, n. especial, pp. 48-55, Mar. 2017.

[34] MIRMEHDI, S. M., TONOLI, G. H. D., DABBAGH, F., "Lignocellulose polyethylene composite: influence of delignification, filler content and filler type", Cellulose Chemistry and Technology, v. 51, n. 3-4, pp. 341-346, May 2017.

[35] GARCÍA, M., GARMENDIA, I., GARCÍA, J., "Influence of natural fiber type in eco-composites", Journal of Applied Polymer Science, v. 107, pp. 2994-3004, Mar. 2008.

[36] KHOFFI, F., KHENOUSSI, N., HARZALLAH, O., et al., "Mechanical behavior of polyethylene terephthalate/copper composite filament", Physics Procedia, v. 21, pp. 240-245, Nov. 2011.

[37] REDIGHIERI, K.I., COSTA, D.A., "Compósitos de polietileno reciclado e partículas de madeira de reflorestamento tratadas com polietileno modificado", Polímeros, v. 18, n. 1, pp. 5-11, Jan./Mar. 2008.

[38] FELDMAN, D., BARBALATA, A. A Synthetic Polymers technology properties applications, 1 ed., London, Chapman and Hall, 1996.

[39] BECKER, D., KLEINSCHMIDT, A.C., BALZER, P.S., et al., "Influência da sequência de mistura do PP-MA nas propriedades dos compósitos de PP e fibra de bananeira", Polímeros. v. 21, n. 1, pp. 7-12, Feb. 2011.

[40] SANTOS, R.P.O., CASTRO, D.O., RUVOLO-FILHO, A.C., et al., "Processing and thermal properties of composites based on recycled PET, sisal fibers, and renewable plasticizers", Journal of Applied Polymer Science, v. 131, n. 12, pp. 1-13, June 2014.

[41] SOUCY, J., KOUBAA, A., MIGNEAILT, S., et al., "The potential of paper mill sludge for woodplastic composites", Industrial Crops and Products, v. 54, pp. 248-256, Mar. 2014. 